\title{
GRANITE QUARRYING PROJECTS AND THEIR IMPACT ON THE ENVIRONMENT
}

\author{
K N J Katupotha \\ Department of Geography, \\ University of Sri Jayewardenepura
}

Surface and subsurface charnockitic gneissic boulders of the Kolonna Divisional Secretariat area have been separated'and detached using bores and compressor machines to produce "blocks" for export. Four granite-quarrying projects were in operation at the Lanka-Beriya Estate, Bulutota Kadamuduna, near the Circuit Bungalow at Bulutota Kadamuduna and at Udahakanda village (Pitakanda). However quarrying in the above four sites has been abondoned stopped consequent to pressure brought by the public. Only one project is active at the Aigburth Estate in Suriyakanda to date.

This study aims at identifying the existing problems of the quarrying projects, examines how these quarrying projects can contribute to slope failure in the future; and makes recommendations as mitigatory measures for better understanding of uses and the management of resources. Accordingly, following conclusions can be made regarding the exploitation activities in the sites:

(a) local relief and other geographical parameters (physical and social) have not been given and concern prior to exploitation of the resources

(b) damaged and destroyed boulders and fragments have been dispersed and have dumped in the sites

(c) reservations made by Ordinances and Laws for natural streams (Poddana, Bulutota and Ittakanda GNDs), electrical transmission lines and cemeteries (Ittakanda GND) have been ignored during these exploration

(d) after removal of boulders, pits burrows have not been filled properly with compacted earth

(e) trees and vegetative species have been destroyed and growth retarded due to operations carried out (Bulutota Kadamuduna, Aigbirth Estate and Udahakanda village

(f) vibration during drilling and dynamiting (dynamiting is not presently used) have created surface cracks in the area immediately behind the boulders

(g) dust from drilling operations are removed by wind and create environmental and health hazards

(h) development of gullies and surface erosion is caused by heavy rains after blocks are removed; and

(i) closed pits as well as the open pi is of the area are able to create gullies by surface erosion and can store an extensive volume of water increasing sub-surface erosion It is evident from detailed field inspections and slope analysis around the sites that illegal and unmethodical quarrying of these boulders in whatever form contributes to slope failure and exerts a negative impact on the environment. The threats to human life and property as well as the degradation of the environment has contributed to a strong opposition by the public to the operation of quarries.

Proceedings of the Eighth Annual Forestry ard Environment Symposium 2002 of the Department of Forestry and Environmental Science, University of Sri Jayewardenepura, Sri Lanka 